\title{
Research on Chloride Penetration Resistance of Hybrid Fiber Reinforced Self-Compacting Concrete
}

\author{
Wu-Jian Long, Zhe-Ming Mai, Jin-Guang Shi, Tian-Tian Zhao, and Wu-Lei Peng \\ Guangdong Provincial Key Laboratory of Durability for Marine Civil Engineering, \\ College of Civil Engineering, Shenzhen University
}

\begin{abstract}
The properties of chloride penetration of hybrid fiber reinforced self-compacting concrete (SCC) were investigated in this study. The results show that the chloride penetration resistance of concrete can be improved by single incorporation either carbon or cellulose fibers. The concrete chloride diffusion coefficient $D_{\mathrm{RCM}}$ of 12 -cm length carbon SCC with fiber content of $1.7,2.72$, and $3.4 \mathrm{~kg} / \mathrm{m}^{3}$ decreases by $10.3,25.5$, and $18.2 \%$ compared to reference concrete without any fibers, respectively. Moreover, the concrete chloride diffusion coefficient $D_{\mathrm{RCM}}$ of cellulose SCC with fiber content of $1.2,1.6$, and $2.0 \mathrm{~kg} / \mathrm{m}^{3}$ decreases by $18.8,22.4$, and $26.7 \%$ compared to reference concrete, respectively. Based on the results of orthogonal experimental design, the chloride diffusion coefficients $D_{\mathrm{RCM}}$ of hybrid fiber reinforced SCC are listed in order of importance, as follows: length of carbon fiber > content of carbon fiber > content of cellulose fiber; furthermore, the hybrid of $2.72-\mathrm{kg} / \mathrm{m}^{3}$ carbon fiber with length of $12 \mathrm{~mm}$ and $2.0-\mathrm{kg} / \mathrm{m}^{3}$ cellulose fiber exhibits the most significant effect on chloride diffusion coefficients $D_{\mathrm{RCM}}$ of SCC.
\end{abstract}

Keywords: carbon fiber, cellulose fiber, hybrid fiber, self-compacting concrete, impermeability

\section{INTRODUCTION}

Resistance to chloride ion penetrability is an important index for measuring durability of concrete (Neville, 1996), so it is one of critical means for strengthening durability of concrete by increasing its impermeability. At present, related research has suggested that chloride ion migration and damage to concrete cover are major causes of reinforcement corrosion for reinforced concrete (Aïtcin, 1998; Neville, 1996). The corrosion of reinforcing bars and changes in corrosion current depend largely on the impermeability of the concrete and the cover thickness over the reinforcement.

Limited information is available regarding the influence of SCC on in situ corrosion performance (ACI Committee 237, 2004). The lack of static stability of plastic SCC can lead to bleeding and segregation, and weaken the quality of the interface between cement paste and embedded reinforcement with direct influence on corrosion resistance (Long, Khayat, Lemieux, Hwang, \& Han, 2014). Densification of the cement matrix and increase in concrete cover in wellcured and uncracked concrete can reduce the risk of corrosion due to ingress of chloride ions.

Using different reinforcing fibers in concrete to make fiber reinforced concrete (FRC) is an effective method in preventing crack propagation and compensating shrinkage induced by low tensile strength (Barluenga \&
Hernández-Olivares, 2007; Cao, Zhang, \& Lv, 2014; Farhad \& Shami, 2013; Pająk \& Ponikiewski, 2013; Sivakumar \& Santhanam, 2007). The most important properties of fiber concrete are energy absorption, formability, and resistance against strikes. These characteristics help FRC to play an important role in concrete technology and to be a cost-effective material in structural issues (Alberti, Enfedaque, \& Gálvez, 2014; Ardanuy, Claramunt, Dias, \& Filho, 2015; Banthia, Majdzadeh, Wu, \& Bindiganavile, 2014; Jiang, Fan, Wu, \& Chen, 2014; Khayat \& Roussel, 2000; Nehdi and Ladanchuk, 2004).

\section{EXPERIMENTS}

\subsection{Raw materials}

In this experiment, P.O. 42.5R ordinary Portland cement manufactured by China Resources Cement (Fengkai) Co., Ltd. was used. Its physical and chemical indices are shown in Table 1. Class II Fly ash was supplied by Guangzhou Zhujiang Cement Co., Ltd. Coarse aggregate was from Antuo Shan, Shenzhen, and continuously graded with a fineness module of 3.59 . Made from sea sand of Shenzhen, fine aggregate was flushed by clear water and its fineness module equaled to 3.59. WS-PC set retarder and polycarboxylates high range water-reducing admixture (HRWRA) was produced by Shenzhen Wushan New Materials Co., Ltd. 
Table 1. Performance index of Portland cement.

\begin{tabular}{|c|c|c|c|c|}
\hline $\begin{array}{c}\text { Specific } \\
\text { surface area } \\
\left(\mathrm{m}^{3} / \mathrm{kg}\right)\end{array}$ & $\begin{array}{c}\text { Normal } \\
\text { consistency } \\
(\%)\end{array}$ & $\begin{array}{l}\text { Ignition } \\
\text { loss } \\
(\%)\end{array}$ & $\begin{array}{c}\text { Chloride } \\
\text { ion } \\
(\%)\end{array}$ & $\begin{array}{c}\text { Alkali } \\
\text { content } \\
(\%)\end{array}$ \\
\hline 370 & 25.5 & 4.01 & 0.01 & 0.4 \\
\hline $\begin{array}{l}\mathrm{SO}_{3} \\
(\%)\end{array}$ & $\begin{array}{c}\mathrm{MgO} \\
(\%)\end{array}$ & $\begin{array}{c}\text { Amount } \\
\text { of } \\
\text { admixture } \\
(\%)\end{array}$ & $\begin{array}{l}\text { Content } \\
\text { of } \\
\text { gypsum } \\
(\%)\end{array}$ & \\
\hline 2.21 & 1.54 & 10.1 & 5.5 & \\
\hline
\end{tabular}

In this experiment, chopped carbon fiber with different length (including 6, 12, and $20 \mathrm{~mm}$ ) manufactured by Nanjing Weida Composite Materials Co., Ltd, was used. Its physical and mechanical properties are shown in Table 2. Cellulose fiber was Duline UF500 cellulose from Beijing Ronel Engineering Materials Co., Ltd. Its physical and mechanical properties are shown in Table 3.

Table 2. Physical and mechanical properties of carbon fiber.

\begin{tabular}{cccc}
\hline $\begin{array}{c}\text { Filament } \\
\text { diameter } \\
(\mu \mathrm{m})\end{array}$ & $\begin{array}{c}\text { Tensile } \\
\text { strength } \\
(\mathrm{GPa})\end{array}$ & $\begin{array}{c}\text { Tensile } \\
\text { modulus } \\
(\mathrm{GPa})\end{array}$ & $\begin{array}{c}\text { Carbon } \\
\text { content } \\
(\%)\end{array}$ \\
\hline $15.0-20.0$ & $3.6-3.8$ & $240-280$ & $\geq 95 \%$ \\
\hline $\begin{array}{c}\text { Extensibility } \\
(\%)\end{array}$ & $\begin{array}{c}\text { Density } \\
\left(\mathbf{g} / \mathbf{c m}^{3}\right)\end{array}$ & $\begin{array}{c}\text { Volume } \\
\text { resistivity } \\
(\omega \cdot \mathbf{c m})\end{array}$ & \\
\hline $1.50 \%$ & $1.6-1.76$ & $1.5 \times 10^{-3}$ & \\
\hline
\end{tabular}

Table 3. Physical and mechanical properties of cellulose fiber.

\begin{tabular}{ccc}
\hline $\begin{array}{c}\text { Filament diameter } \\
(\mu \mathrm{m})\end{array}$ & $\begin{array}{c}\text { Specific gravity } \\
\left(\mathbf{g} / \mathbf{c m}^{\mathbf{3}}\right)\end{array}$ & $\begin{array}{c}\text { Fiber length } \\
(\mathbf{m m})\end{array}$ \\
\hline 19.2 & $1.0-1.2$ & 2.2 \\
\hline $\begin{array}{c}\text { Tensile strength } \\
(\mathrm{MPa})\end{array}$ & $\begin{array}{c}\text { Elasticity modulus } \\
(\mathbf{M P a})\end{array}$ & $\begin{array}{c}\text { Denier } \\
(\mathbf{g} / 900 \mathbf{m})\end{array}$ \\
\hline 751 & $9.2 \times 10^{3}$ & 2.5
\end{tabular}

\subsection{Mix proportion}

In this experiment, concrete was mixed with water at $212.8 \mathrm{~kg} / \mathrm{m}^{3}$, cement at $448 \mathrm{~kg} / \mathrm{m}^{3}$, fly ash at $448 \mathrm{~kg} / \mathrm{m}^{3}$, coarse aggregate at $870 \mathrm{~kg} / \mathrm{m}^{3}$, and fine aggregate at $712 \mathrm{~kg} / \mathrm{m}^{3}$. An experimental scheme was designed through an orthogonal experiment to investigate resistance of hybrid fiber reinforced SCC to chloride ion penetrability. Level and factors of the orthogonal experiment are shown in Table 4. Orthogonal level and factor design are shown in Table 5.
Table 4. Factors and levels of orthogonal test.

\begin{tabular}{cccc}
\hline Levels & $\begin{array}{c}\text { F (Carbon } \\
\text { fiber length/ } \\
\mathbf{m m}\end{array}$ & $\begin{array}{c}\text { B (Carbon } \\
\text { fiber content/ } \\
\mathbf{k g} / \mathbf{m}^{3} \text { ) }\end{array}$ & $\begin{array}{c}\mathbf{C} \text { (Cellulose } \\
\text { fiber content/ } \\
\mathbf{~ k g} / \mathbf{m}^{3} \text { ) }\end{array}$ \\
\hline 1 & 6 & 1.7 & $0.60 \%$ \\
2 & 12 & 12 & $0.80 \%$ \\
3 & 20 & $1.70 \%$ & $1.00 \%$ \\
\hline
\end{tabular}

Table 5. Orthogonal trial.

\begin{tabular}{|c|c|c|c|}
\hline \multirow[b]{2}{*}{ No. } & \multicolumn{3}{|c|}{ Factors } \\
\hline & $\begin{array}{c}\text { A (Carbon } \\
\text { fiber length/ } \\
\mathrm{mm} \text { ) }\end{array}$ & $\begin{array}{c}\text { B (Carbon } \\
\text { fiber length/ } \\
\mathrm{kg} / \mathrm{m}^{3} \text { ) }\end{array}$ & $\begin{array}{c}\text { C (Cellulose } \\
\text { fiber content/ } \\
\left.\mathrm{kg} / \mathrm{m}^{3}\right)\end{array}$ \\
\hline 11 & $1(6)$ & $1(1.7)$ & $1(1.2)$ \\
\hline 12 & $2(12)$ & 1 & $2(1.6)$ \\
\hline 13 & $3(20)$ & 1 & $3(2.0)$ \\
\hline 14 & 1 & $2(2.72)$ & 2 \\
\hline 15 & 2 & 2 & 3 \\
\hline 16 & 3 & 2 & 1 \\
\hline 17 & 1 & $3(3.4)$ & 3 \\
\hline 18 & 2 & 3 & 1 \\
\hline 19 & 3 & 3 & 2 \\
\hline
\end{tabular}

In this experiment, there were mainly 19 groups, among which the first group was the Control Group, the 2 nd to 7 th groups were mainly about singledoped carbon fiber for focusing on exploring length and doping amount of carbon fiber, the 8th to 10th groups were about single-doped cellulose fiber mainly for investigating doping amount of cellulose, the 11th to 19th groups were about orthogonal experimental design primarily for examining impacts of doping amount of cellulose fiber, length, and doping amount of carbon fiber on properties of hybrid fiber reinforced SCC. Experiment number and doping amount of fiber are shown in Table 6.

\subsection{Experimental procedure}

This experiment was performed according to Chinese Standard GB/T 50082 - 2009 "Standard for Test Methods of Long-term Performance and Durability of Ordinary Concrete." The 100-mm high molds with a diameter of $50 \mathrm{~mm}$ were used. The specimens were demolded at $24 \mathrm{~h}$ and then submerged in a pond of a standard curing room. These specimens were processed 7 days ahead of the chloride ion penetration test. In this experiment, middle parts $(50 \pm 2 \mathrm{~mm})$ of specimen were taken. 
Table 6. Serial number and fiber content.

\begin{tabular}{|c|c|c|c|}
\hline No. & $\begin{array}{l}\text { Carbon fiber } \\
\text { length }(\mathrm{mm})\end{array}$ & $\begin{array}{l}\text { Carbon fiber } \\
\text { length }\left(\mathrm{kg} / \mathrm{m}^{3}\right)\end{array}$ & $\begin{array}{l}\text { Cellulose fiber } \\
\text { content }\left(\mathrm{kg} / \mathrm{m}^{3}\right)\end{array}$ \\
\hline 1 & - & - & - \\
\hline 2 & 6 & 1.7 & - \\
\hline 3 & 6 & 2.72 & - \\
\hline 4 & 6 & 3.4 & - \\
\hline 5 & 12 & 1.7 & - \\
\hline 6 & 12 & 2.72 & - \\
\hline 7 & 12 & 3.4 & - \\
\hline 8 & - & - & 1.2 \\
\hline 9 & - & - & 1.6 \\
\hline 10 & - & - & 2.0 \\
\hline 11 & 6 & 1.7 & 1.2 \\
\hline 12 & 6 & 2.72 & 1.6 \\
\hline 13 & 6 & 3.4 & 2.0 \\
\hline 14 & 12 & 1.7 & 1.6 \\
\hline 15 & 12 & 2.72 & 2.0 \\
\hline 16 & 12 & 3.4 & 1.2 \\
\hline 17 & 20 & 1.7 & 2.0 \\
\hline 18 & 20 & 2.72 & 1.2 \\
\hline 19 & 20 & 3.4 & 1.6 \\
\hline
\end{tabular}

Steady-state chloride ion migration coefficient of concrete was calculated as follows:

$$
\begin{aligned}
D_{\mathrm{RCM}}= & \frac{0.0239 \times(273+T) L}{(\mathrm{U}-2) t} \\
& \left(X_{\mathrm{d}}-0.0238 \sqrt{\frac{((273+T) L) X_{\mathrm{d}}}{\mathrm{U}-2}}\right)
\end{aligned}
$$

where $D_{\mathrm{RCM}}$ was steady-state chloride ion migration coefficient and accurate to $0.1 \times 10^{-12} \mathrm{~m}^{2} / \mathrm{s}$;

$V$ was absolute value of voltage $(\mathrm{V})$;

$T$ was mean of initial and final temperature of anode solution $\left({ }^{\circ} \mathrm{C}\right)$;

$L$ was thickness of specimens and accurate to $0.1 \mathrm{~mm}$; $X_{d}$ was mean penetration depth of chloride ions $(\mathrm{mm})$ and accurate to $0.1 \mathrm{~mm}$;

$t$ was duration of the experiment (h).

In each group, arithmetic mean of chloride ion migration coefficient of three specimens was considered as migration coefficient of that group of chloride ions.

Water tank used in the experiment on chloride ion penetrability experiment is shown in Figure 2.

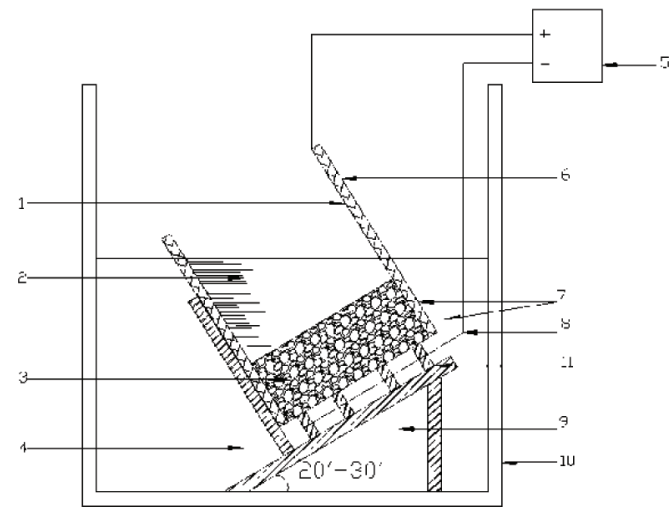

Figure 1. Test setup of RCM. 1 - anode plate; 2 - anode solution; 3 - specimens; 4 - cathode solution; 5 - stable DC power source; 6 - organic silicon rubber bushing; 7 - hoop; 8 - cathode plate; 9 - bracket; 10 - test pit; and 11 - end support.

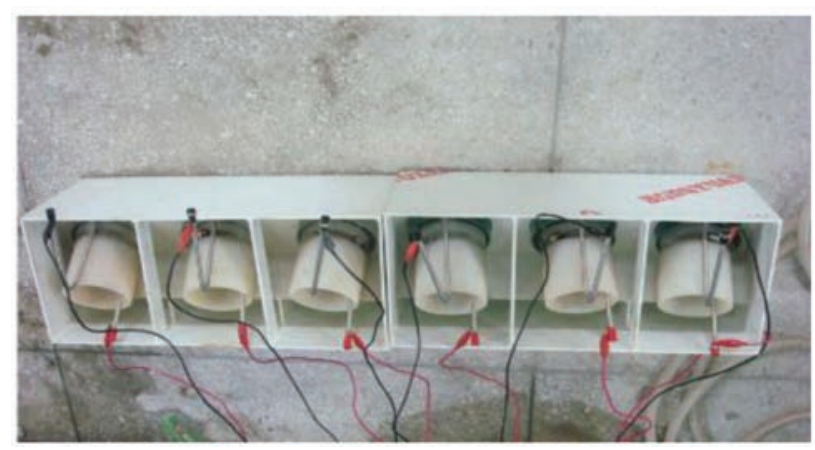

Figure 2. Tank of RCM equipment.

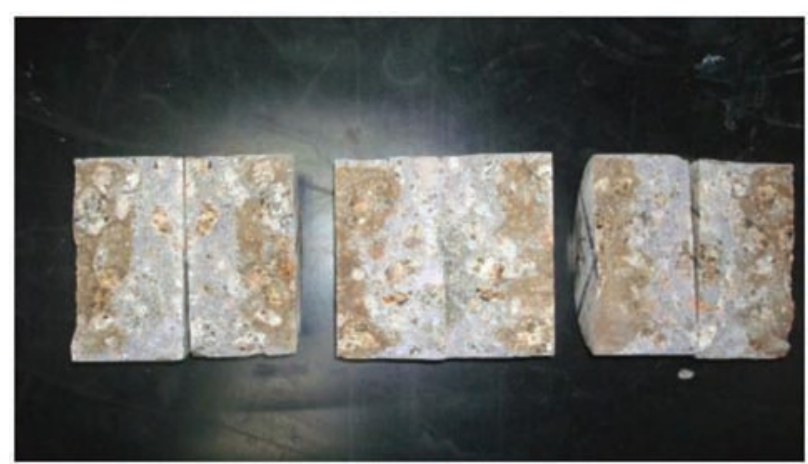

Figure 3. Chloride ion penetration depth of RCM test.

Chloride ion migration depth of RCM experiment is shown in Figure 3.

\section{EXPERIMENTAL RESULTS AND ANALYSIS}

In this range of experiments, $D_{\mathrm{RCM}}$ (chloride ion migration coefficient) is shown in Table 7. 
Table 7. Chloride ion penetration coefficient $D_{\mathrm{RCM}}$.

\begin{tabular}{cccccccc}
\hline $\begin{array}{c}\text { Experiment } \\
\text { group }\end{array}$ & $\mathbf{1}$ & $\mathbf{2}$ & $\mathbf{3}$ & $\mathbf{4}$ & $\mathbf{5}$ & $\mathbf{6}$ & $\mathbf{7}$ \\
\hline $\begin{array}{c}D_{\mathrm{RCM}} \\
\left(\times 10-12 \mathrm{~m}^{2} / \mathrm{s}\right)\end{array}$ & 16.5 & 15.3 & 13.9 & 14.7 & 14.8 & 12.3 & 13.5 \\
\hline $\begin{array}{c}\text { Experiment } \\
\text { group }\end{array}$ & $\mathbf{8}$ & $\mathbf{9}$ & $\mathbf{1 0}$ & $\mathbf{1 1}$ & $\mathbf{1 2}$ & $\mathbf{1 3}$ \\
\hline $\begin{array}{c}D_{\mathrm{RCM}} \\
\left(\times 10-12 \mathrm{~m}^{2} / \mathrm{s}\right)\end{array}$ & 13.4 & 12.8 & 12.1 & 12.5 & 13.1 & 11.7 \\
\hline $\begin{array}{c}\text { Experiment } \\
\text { group }\end{array}$ & 14 & $\mathbf{1 5}$ & $\mathbf{1 6}$ & $\mathbf{1 7}$ & $\mathbf{1 8}$ & $\mathbf{1 9}$ \\
\hline $\begin{array}{c}D_{\mathrm{RCM}} \\
\left(\times 10-12 \mathrm{~m}^{2} / \mathrm{s}\right)\end{array}$ & 11.4 & 12.8 & 12.3 & 12.7 & 11.5 & 11.6 \\
\hline
\end{tabular}

\subsection{Impacts of carbon fiber on penetrability}

Impacts of carbon fiber with different lengths $(6$ and $12 \mathrm{~mm})$ and doping amount $\left(1.7,2.72\right.$, and $\left.3.4 \mathrm{~kg} / \mathrm{m}^{3}\right)$ on $D_{\mathrm{RCM}}$ of SCC chloride ion are shown in Figure 4.

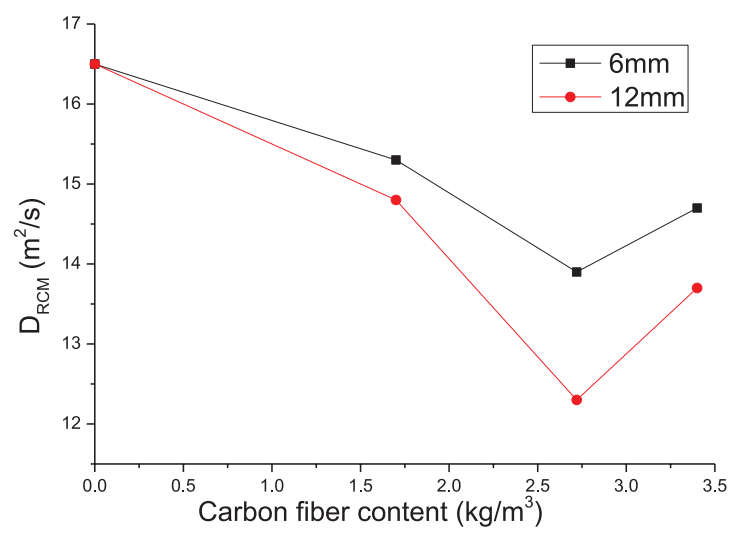

Figure 4. The impact of carbon fiber length and content on $D_{\mathrm{RCM}}$.

From Figure 4, it may be known that $D_{\mathrm{RCM}}$ decreases with the increase in doping amount of chloride ions ranging from 0 to $2.74 \mathrm{~kg} / \mathrm{m}^{3}$ for carbon fiber of two different lengths (namely, 6 and $12 \mathrm{~mm}$ ), whereas resistance of concrete to chloride ion penetrability increases. As the fiber is doped at a volume above $2.74 \mathrm{~kg} / \mathrm{m}^{3}, D_{\mathrm{RCM}}$ increases with the increase of doping amount, but the resistance of concrete to chloride ion is weakened.

As shown in Figure 4, impacts of carbon fiber on $D_{\mathrm{RCM}}$ of SCC differ in case of different lengths. As such fibers of two different lengths were doped with 1.7, 2.72, and $3.4 \mathrm{~kg} / \mathrm{m}^{3}$, the coefficient declined by $7.27,15.76$, and $10.91 \%$, respectively, for $6-\mathrm{mm}$ carbon fiber, but fell by $10.30,25.45$, and $18.18 \%$, respectively, for $12-\mathrm{mm}$ long carbon fiber. From the figure, it may be known that when in case of the same doping amount, 12-mm long carbon fiber has weaker impacts on $D_{\mathrm{RCM}}$ of concrete than 6-mm long carbon fiber.

\subsection{Impacts of cellulose fiber on penetrability}

Impacts of doping amount of cellulose fiber on $D_{\mathrm{RCM}}$ of SCC are shown in Figure 5.

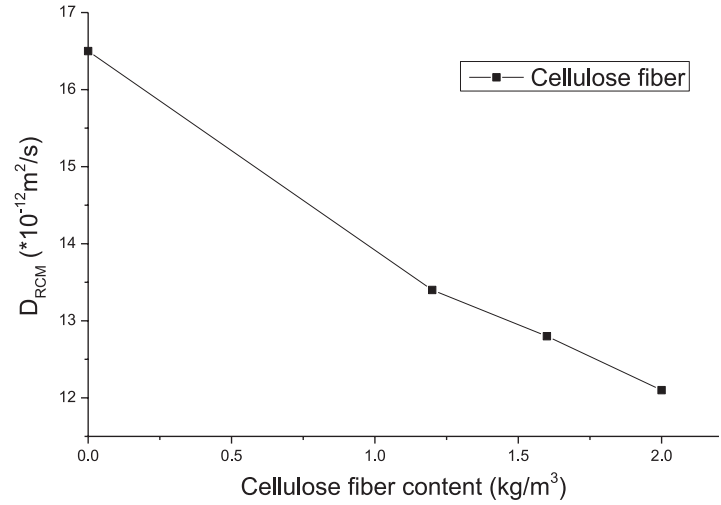

Figure 5. The impact of cellulose fiber content on $D_{\mathrm{RCM}}$.

It may be found from Figure 5 that cellulose fiber imposes different impacts on $D_{\mathrm{RCM}}$ when it is applied at $1.2,1.6$, and $2.0 \mathrm{~kg} / \mathrm{m}^{3}$, respectively. Compared with reference concrete, the coefficient of concrete doped with cellulose fiber decreased by 18.79, 22.42, and $26.67 \%$, respectively. It may be seen from Figure 5 that $D_{\mathrm{RCM}}$ declined with the increase in doping amount of cellulose fiber within a volume from 0 to $2.0 \mathrm{~kg} / \mathrm{m}^{3}$.

\subsection{Orthogonal experimental results and analysis}

Impacts of length of carbon fiber, and doping amount of carbon fiber and cellulose fiber on $D_{\mathrm{RCM}}$ of concrete were mainly examined. Table 8 shows results about the $D_{\mathrm{RCM}}$ and the intuitive analysis.

Table 8. Test results and analysis of $D_{\mathrm{RCM}}$.

\begin{tabular}{|c|c|c|c|c|}
\hline No. & $\begin{array}{c}\text { Carbon } \\
\text { fiber } \\
\text { length } \\
(\mathrm{mm})\end{array}$ & $\begin{array}{c}\text { Carbon } \\
\text { fiber } \\
\text { content } \\
\left(\mathrm{kg} / \mathrm{m}^{3}\right)\end{array}$ & $\begin{array}{c}\text { Cellulose } \\
\text { fiber } \\
\text { content } \\
\left(\mathrm{kg} / \mathrm{m}^{3}\right) \\
\end{array}$ & $\begin{array}{c}D_{\mathrm{RCM}} \\
(\times 10- \\
\left.12 \mathrm{~m}^{2} / \mathrm{s}\right)\end{array}$ \\
\hline 11 & 6 & 1.7 & 1.2 & 12.5 \\
\hline 12 & 6 & 2.72 & 1.6 & 13.1 \\
\hline 13 & 6 & 3.4 & 2 & 11.7 \\
\hline 14 & 12 & 1.7 & 1.6 & 11.4 \\
\hline 15 & 12 & 2.72 & 2 & 10.8 \\
\hline 16 & 12 & 3.4 & 1.2 & 12.3 \\
\hline 17 & 20 & 1.7 & 2 & 12.7 \\
\hline 18 & 20 & 2.72 & 1.2 & 11.5 \\
\hline 19 & 20 & 3.4 & 1.6 & 11.6 \\
\hline K1 & 37.3 & 36.6 & 36.3 & \\
\hline K2 & 34.5 & 35.4 & 36.1 & \\
\hline K3 & 35.8 & 35.6 & 35.2 & \\
\hline k1 & 12.43 & 12.20 & 12.10 & \\
\hline k2 & 11.50 & 11.80 & 12.03 & \\
\hline k3 & 11.93 & 11.87 & 11.73 & \\
\hline Range & 0.93 & 0.40 & 0.37 & \\
\hline Order & $A>B>C$ & & & \\
\hline Optimization levels & $\mathrm{A}_{2}$ & $\mathrm{~B}_{2}$ & $\mathrm{C}_{3}$ & \\
\hline Optimal combination & $\mathrm{A}_{2} \mathrm{~B}_{2} \mathrm{C}_{3}$ & & & \\
\hline
\end{tabular}


According to intuitive analysis of Table 8, length of carbon fiber had the most significant impacts on $D_{\mathrm{RCM}}$ of hybrid fiber reinforced SCC when the concrete was doped with 6,12 , and $20-\mathrm{mm}$ long carbon fiber at $1.70,2.72$, and $3.40 \mathrm{~kg} / \mathrm{m}^{3}$ and cellulose fiber at 1.20 , 1.60 , and $2.00 \mathrm{~kg} / \mathrm{m}^{3}$, respectively, followed by doping amount of carbon fiber and cellulose fiber successively. In case of only considering impermeability of concrete, it is best to dope the concrete with 12-mm long carbon fiber at $2.72 \mathrm{~kg} / \mathrm{m}^{3}$ and cellulose fiber at $2.0 \mathrm{~kg} / \mathrm{m}^{3}$. Under this situation, hybrid fiber has the most significant impacts on $D_{\mathrm{RCM}}$ of concrete.

\section{ANALYSIS ON MECHANISM OF FIBER}

Cellulose fiber is highly dispersive, so it is effective for cellulose fiber to effectively scatter in cement-based materials to form an effective support system by doping SCC with the fiber. The fiber may not only reduce undesirable phenomena such as water extraction and aggregate separation but also effectively reduce bleeding and strengthen cohesiveness of SCC. Therefore, it does not only decrease internal bleeding passage of concrete but also reduces its connected pore channel. Microscopically, it decreases porosity and enhances compactness of concrete, thereby greatly increasing impermeability of the concrete.

It is effective for obstructing connected pores by doping the concrete with carbon fiber and cellulose fiber to transform originally connected pores into closed holes. However, current pertinent research has suggested that apart from internal porosity of concrete, its internal connected pores also have close associations with chloride ion migration. Thus, it is not only effective for controlling migration of chloride ions inside fiber reinforced SCC but also favorable for decreasing its migration coefficient, finally strengthening its impermeability.

The acting mechanism of doping SCC is the same for enhancing resistance to chloride ion penetrability and early crack resistance, because it is effective to generate crack-resistant effect and thus inhibit formation of early plastic cracks by doping concrete with fiber. According to theories of composite materials, early crack resistance of SCC is strengthened when it is doped with fiber which may bear stress. As fiber is resistant to crack, hardened SCC will have higher crack resistance. As a result, cracks will be effectively inhibited and formation of penetrating cracks may be reduced.

\section{CONCLUSION}

(1) Carbon fiber has different impacts on $D_{\mathrm{RCM}}$ of SCC in case of different lengths. When the doping amount is the same, the coefficient is lower for $12-\mathrm{mm}$ carbon fiber than that for 6-mm carbon fiber, and the impermeability of concrete is better for $12-\mathrm{mm}$ carbon fiber than $6-\mathrm{mm}$ long carbon fiber.

(2) Carbon fiber affects $D_{\mathrm{RCM}}$ of concrete differently when the doping amount differs. When concrete is doped with 6 and 12- $\mathrm{mm}$ carbon fiber at a volume ranging from 0 to $2.74 \mathrm{~kg} / \mathrm{m}^{3}, D_{\mathrm{RCM}}$ of concrete will decline with the increase in doping amount, whereas the resistance to chloride ion penetrability is strengthened. As the concrete was doped with carbon fiber at a volume higher than $2.74 \mathrm{~kg} / \mathrm{m}^{3}, D_{\mathrm{RCM}}$ will rise with the increase in doping amount and the resistance to chloride ion penetrability will be weakened.

(3) As the concrete was doped with cellulose fiber at $1.2,1.6$, and $2.0 \mathrm{~kg} / \mathrm{m}^{3}$, the $D_{\mathrm{RCM}}$ will decline by $18.79,22.42$, and $26.67 \%$, respectively.

(4) According to analytical results of orthogonal experiments, $D_{\mathrm{RCM}}$ of hybrid fiber reinforced SCC is influenced by length of carbon fiber to the largest extent, followed by doping amount of carbon fiber and cellulose fiber, respectively.

\section{ACKNOWLEDGMENTS}

The authors gratefully acknowledge the financial support provided by the National Natural Science Foundation of China (No. 51278306 and 51578341) and the Science Industry, Trade and Information Technology Commission of Shenzhen Municipality (No. JCYJ20140418095735540).

\section{REFERENCES}

ACI Committee 237. (2004). Guidelines on selfconsolidating concrete. Farmington Hills, $\mathrm{MI}$ : ACl.

Aïtcin, P. C. (1998). High-performance concrete. London, England: E \& FN Spon, p. 591.

Alberti, M. G., Enfedaque, A., \& Gálvez, J. C. (2014). On the mechanical properties and fracture behavior of polyolefin fiber-reinforced selfcompacting concrete. Construction and Building Materials, 55, 274-288.

Ardanuy, M., Claramunt, J., Dias, R., \& Filho, T. (2015). Cellulosic fiber reinforced cementbased composites: A review of recent research. Construction and Building Materials, 79, 115-128.

Banthia, N., Majdzadeh, F., Wu, J., \& Bindiganavile, V. (2014). Fiber synergy in hybrid fiber reinforced concrete (HyFRC) in flexure and direct shear. Cement and Concrete Composites, 48, 91-97.

Barluenga, G., \& Hernández-Olivares, F. (2007). Cracking control of concretes modified with short AR-glass fibers at early age: Experimental results on standard concrete and SCC. Cement and Concrete Research, 37(12), 1624-1638. 
Cao, M. L., Zhang, C., \& Lv, H. F. (2014). Mechanical response and shrinkage performance of cementitious composites with a new fiber hybridization. Construction and Building Materials, 57, 45-52.

Farhad, A., \& Shami, N. (2013). Self-compacting concrete incorporating steel and polypropylene fibers: Compressive and tensile strengths, moduli of elasticity and rupture, compressive stress-strain curve, and energy dissipated under compression. Composites Part B Engineering, 53, 121-133.

Jiang, C. H., Fan, K., Wu, F., \& Chen, D. (2014). Experimental study on the mechanical properties and microstructure of chopped basalt fibre reinforced concrete. Materials and Design, 58, 187-193.

Khayat, K. H., \& Roussel, Y. (2000). Testing and performance of fiber-reinforced, self-consolidating concrete. Materials and Structures, 33(6), 391-397.
Long, W. J., Khayat, K. H., Lemieux, G., Hwang, S. D., \& Han, N. X. (2014). Performance-based specifications of workability characteristics of prestressed, precast self-consolidating concrete A North American prospective. Materials, 7 , 2474-2489.

Nehdi, M., \& Ladanchuk, J. D. (2004). Fiber synergy in fiber-reinforced self-consolidating concrete. ACI Materials Journal, 101(6), 491-500.

Neville, A. M. (1996). Properties of concrete (4th ed.). London, England: p. 844. [ISBN: 0-582-23070-5].

Pająk, M., \& Ponikiewski, T. (2013). Flexural behavior of self-compacting concrete reinforced with different types of steel fibers. Construction and Building Materials, 47, 397-408.

Sivakumar, A., \& Santhanam, M. (2007). A quantitative study on the plastic shrinkage cracking in high strength hybrid fibre reinforced concrete. Cement and Concrete Composites, 29(7), 575-581. 